\title{
Sclerostin and bone metabolism markers in hyperthyroidism before treatment and interrelations between them
}

\author{
İlker Sarıtekin1, Serefden Açıkgöz1, Taner Bayraktaroğlu², Fatih Kuzu², Murat Can¹, Berrak \\ Güven1, Görkem Mungan1, Çağatay Büyükuysal³ and Selda Sarıkaya4
}

1Department of Biochemistry, ${ }^{2}$ Department of Endocrine and Metabolism, ${ }^{3}$ Department of Biostatistics, ${ }^{4}$ Department of Physical Medicine and Rehabilitation, Faculty of Medicine, Bülent Ecevit University, 67630 Zonguldak, Turkey

Sclerostin, which is a glycoprotein produced by osteocytes, reduces the formation of bones by inhibiting the Wnt signal pathway. Thyroid hormones are related with Wnt signal pathway and it has been reported that increased thyroid hormones in hyperthyroidism fasten epiphysis maturation in childhood, and increase the risk of bone fractures by stimulating the bone loss in adults. The aim of this study was to examine the sclerostin serum levels, the relation between sclerostin and thyroid hormones as well as the biochemical markers of the bone metabolism in patients with hyperthyroidism (including multinodular goiter and Graves' disease), whose treatments have not started yet. No difference was found in the serum sclerostin levels between the hyperthyroidism group $(n=24)$ and the control group $(n=24)(p=0.452)$. The serum osteocalcin levels and 24hour urinary phosphorus excretion were found to be higher in the hyperthyroid group than in the control group ( $p<0.001, p=0.009$ ). A positive correlation was determined between the sclerostin and bone alkaline phosphatase levels $(p<0.001)$; a negative correlation between the osteocalcin and thyroid stimulating hormone (TSH) $(p<0.05)$; a positive correlation between the osteocalcin and thyroid hormones $\left(\mathrm{FT}_{3}, \mathrm{FT}_{4}\right)(p<0.001)$; and a positive correlation between the deoxypyridinoline and hydroxyproline $(p<0.001)$. No correlation was determined between sclerostin and $\mathrm{TSH}_{1} \mathrm{FT}_{3}, \mathrm{FT}_{4}(p>0.05)$. Therefore, we consider that a long-term study that covers the pre-post treatment stages of hyperthyroidism, including both the destruction and construction of the skeleton would be more enlightening. Moreover, the assessment of the synthesis of sclerostin in the bone tissue and in the serum level might show differences.

Key words: hyperthyroidism, sclerostin, bone metabolism markers Received: 20 April, 2016; revised: 05 July, 2017; accepted: 03 August, 2017; available on-line: 25 October, 2017

e-mail: serefdenacikgoz@yahoo.com

Abbreviations: ALT, alanine transaminase; AST, aspartate transaminase; BALP, bone alkaline phosphatase; BMD, bone mineral density; BMP, bone morphogenetic protein; $\mathrm{Ca}$, calcium; DPD, deoxypyridinoline; ELISA, enzyme-linked immuno sorbent assay; FT3, free triiyodotironin (free thyroid hormone 3); FT4, free tetraiyodo-L-tironin (thyroxine); GGT, y glutamyl transpeptidase; ISCD, international society for clinical densitometry; $\mathrm{P}$, phosphorus; RANKL, nuclear factor $\mathrm{KB}$ receptor activator ligand; $\mathrm{TSH}$, thyroid stimulating hormone

\section{INTRODUCTION}

Thyroid hormones have a regulatory effect on cellular metabolism in several tissues, which is important in nutrition and mineral metabolism, thermogenesis, cardiovascular system, stimulation of growth and development of various tissues at critical periods, including the central nervous system and skeleton (Ogilvy-Stuart, 2002). Thyroid hormones play significant roles in bone formation in fetal life, bone modelling during childhood and remodelling in adults (Ben-Shlomo et al., 2001). On the other hand, it has been reported that hyperthyroidism has a lifelong influence on bone tissues, in that it may accelerate epiphyseal maturation by increasing bone mineralization in childhood, and may induce bone loss in adults (Cardoso et al., 2014). As a result, this increases the risk of bone fractures (Vestergaard et al., 2000; Basset et al., 2007). During the bone formation, T3 stimulates osteoblast differentiation and activity by direct influence on thyroid receptors as well as it induces growth factors (IGF-1, its receptor), osteocalcin, type 1 collagen, alkaline phosphatase and metalloproteinases. T3 also stimulates osteoclast differentiation and activity, but it still remains unclear whether the effects of $\mathrm{T} 3$ on bone resorption result from direct actions in osteoclasts or indirectly through effects on osteoblasts. During the bone resorbtion, T3 stimulates factors that are important in the differentiation of osteoclasts such as interleukin-6,8, prostaglandin-E2 and RANKL. T3 also has synergistic effects with osteoclastogenic hormones such as vitamin $\mathrm{D}$ and parathormone (Cardoso et al., 2014). The effects of thyroid hormones on the bone formation and bone loss might occur via Wnt/ $\beta$-catenin signaling pathway (O'shea et al., 2012; Tsourdi et al., 2015; Wang et al., 2007). Wnt signaling pathway, which consists of several proteins, takes part in the regulation of several features of cells such as cell growing, differentiation, function and death (Krishnan et al., 2006).

Sclerostin is a glycoprotein, which is mainly produced in osteocytes. It is a product of sclerostin gene and it reduces bone formation in osteoblasts by inhibiting Wnt signaling pathway (Van Bezooijen et al. 2004, 2007; Lin et al., 2009). In gene encoding sclerostin knockout mice, a phenotype with high bone mass, similar to sclerostosis patients, was observed (Xiaodong et al., 2008). On the contrary, rats overexpressing sclerostin gene exhibited low bone mass (Winkler et al., 2003). Lin et al. (2009) in wildtype mice with avoided mechanical loading, demonstrated increased synthesis of sclerostin in opposition to decreased Wnt/ $\beta$-catenin signaling. However, the bone loss detected after reduced mechanical loading was not identified in sclerostin negative mice.

Since thyroid hormones and sclerostin have an influence on bone tissues via Wnt signaling pathway, it seemed reasonable to search both of them in hyperthyroidism patients. In this study serum sclerostin levels were studied in hyperthyroidism patients. The relation betwe- 
en sclerostin and thyroid hormones and the relation of both, with bone metabolism markers such as serum BALP, intact osteocalcin as markers for bone formation and urine DPD, $\mathrm{OH}$ proline for bone resorption were investigated.

\section{MATERIALS AND METHODS}

Patients and setting. Twenty four patients with hyperthyroidism, yet untreated, were admitted to the Clinics of Endocrine and Metabolism, and 24 voluntary normal persons were included in the study. The hyperthyroidism group consisted of multinodular goiter and Graves' disease patients. Subacute thyroiditis patients were eliminated. The study was approved by the BEU Clinical Studies Ethics Committee (11.02.2014.2013-138$31 / 12$ ) and informed consents were obtained from the patients. Exclusion criteria were the presence of hormonal disorders other than hyperthyroidism, malabsorption, rheumatic diseases, malignancy, diabetes, hypertension, menopause, smoking and alcohol use, previously suffered drug therapy for thyroid diseases, radiotherapy and surgery of the thyroid gland. Control groups were created as non smoking, alcohol free, healthy men and non menopause women.

Study procedures. Blood and urine samples were obtained from the patients with the diagnosis of hyperthyroidism before the initiation of the therapy. Twentfour-hour urine samples were collected. After 12-hour fasting period, the blood samples were drawn. The samples in the control group were obtained in the same way. After the blood clotted, the samples were centrifuged and aliquots of serum were immediately stored at $-80^{\circ} \mathrm{C}$.

Levels of serum sclerostin were determined using the human sclerostin (SOST) ELISA kit (Bioassay technology laboratory, cat no: E3068Hu, China), serum bone alkaline phosphatase (BALP) using the human BALB ELISA kit (Bioassay technology laboratory, cat no: E1493Hu, China), 24-hour urine deoxypyridinoline (DPD) using the human DPD crosslinks kit (Bioassay technology laboratory, cat. no: E1455 Hu, China) with the double antibody labeled with biotin solid phase sandwich method in an ELISA device (ELX 800 G, BIOTEC Instruments Winooski, USA). All three tests have intra-assay CV of $<8 \%$, interassay CV of $<10 \%$. Levels of serum osteocalcin were determined using the human Osteocalcin ELISA kit (Invitrogen, Life Tecnologies, USA, cat. no: KAQ1381) with the solid phase enzyme amplified sensitivity immunoassay method in an ELISA device (ELX 800 G, BIO-TEC Instruments Winooski, USA). Intra-assay $\mathrm{CV}$ of $<4.7 \%$, interassay $\mathrm{CV}$ of $<3.5 \%$.

The levels of urine hydroxyproline $(\mathrm{OH}$ proline) were measured by using the Bergman \& Loxley (1963) method. The principle of the test was colorimetric measurement of the coloured complex created with p-dimethylaminobenzaldehyde of pyrrole after the oxidation of $\mathrm{OH}$-pyroline to pyrrole compound with chloramine $\mathrm{T}$ using a spectrophotometer (Shimadzu UV 1601, Tokyo, Japan) at $558 \mathrm{~nm}$. As a standard, trans-4-Hydroxy-L-proline (Aldrich) was used. 24-hour urine OH proline/ 24hour urine creatinine ratio was calculated (intra-assay CV of $<5.4 \%)$.

Beckman Coulter, Olympus AU 2700 (Japan) autoanalyzer device was used to determine serum and urine calcium, phophorus, creatinine and serum urea, glucose levels, alanine transaminase (ALT), aspartate transaminase (AST), total alkaline phosphatase (total ALP), $\gamma$ glutamyl transpeptidase (GGT) activity. Serum thyroid stimulating hormone (TSH), free thyroid hormone 3 (FT3), free thyroxine (FT4) levels were studied in the hormone autoanalyzer (Beckman Coulter Unicel DxI 600, USA).

Bone mineral density (BMD) was assessed by measuring lumbar spine and femoral neck bone mineral density in the Hologic QDR4500W (Hologic Inc., Bedford, Massachusetts, USA) device.

Statistical analysis. The Statistical Package for Social Sciences 19.0 (SPSS Inc, Chicago, IL, USA) was used for all data analyses. Descriptive statistics were expressed as mean, standard deviation (S.D.), median, and minimummaximum for continuous variables and frequencies with percent for categorical variables. Shapiro Wilk test was used for test of normality. Student's $t$-test was used to test the significance of differences between hyperthyroidism and normal study groups for normal distributed variables and Mann Whitney U-test for non-normal distributed variables. Yates-corrected chi-square test was used for comparing categorical variables between groups. Spearman correlation analysis was performed to determine the relationship between continuous variables. For all statistical comparisons, a $p$-value below 0.05 was assumed as statistically significant.

Table 1. Levels of serum TSH, FT3, FT4, ALT, AST, GGT, sclerostin, BALB, osteocalcin and 24-hour urine Ca, P, DPD, OH proline / creatinine ratios and $\mathrm{BMI}$ in the hyperthyroidism group and the control group

\begin{tabular}{|c|c|c|c|}
\hline & $\begin{array}{l}\text { Hyperthyroidism group } \\
(n=24)\end{array}$ & $\begin{array}{l}\text { Control group } \\
(n=24)\end{array}$ & $p$ value \\
\hline BMI & $23.95(17.10-32)$ & $25.40(20.80-35.80)$ & $p=0.065$ \\
\hline Serum TSH ( $\mu \mathrm{IU} / \mathrm{mL})$ & $0.02(0.01-0.46)$ & $1.50(0.45-3.85)$ & $* * *$ \\
\hline Serum $\mathrm{FT}_{3}(\mathrm{pg} / \mathrm{mL})$ & $8.57(2.91-27.21)$ & $2.77(1.17-3.79)$ & $* * *$ \\
\hline Serum $\mathrm{FT}_{4}(\mathrm{ng} / \mathrm{dL})$ & $2.71(0.97-5.89)$ & $0.91(0.68-1.86)$ & $* * *$ \\
\hline Serum ALT (IU/L) & $24.5(9-37)$ & $13.5(5-53)$ & * \\
\hline Serum AST (IU/L) & $21.5(12-31)$ & $18.5(12-46)$ & $p=0.311$ \\
\hline Serum GGT (IU/L) & $27.5(11-68)$ & $22.0(9-66)$ & $p=0.577$ \\
\hline Serum sclerostin (ng/mL) & $5.97(2.59-34.74)$ & $7.00(2-32)$ & $p=0.452$ \\
\hline Serum BALP (IU/L) & $90.1(34.4-240)$ & $90.9(34.6-240)$ & $p=0.470$ \\
\hline Serum osteocalcin (ng/mL) & $10.08(0.54-56.62)$ & $3.40(0.17-12.98)$ & *** \\
\hline Urine $\mathrm{mg} \mathrm{Ca/g}$ creatinine/day & $117(21-409)$ & $98(17-218)$ & $p=0.523$ \\
\hline Urine $\mathrm{mg} \mathrm{P} / \mathrm{g}$ creatinine/day & $569(373-1198)$ & $484(211-885)$ & $* *$ \\
\hline Urine nMol DPD/g creatinine/day & $71.9(29.1-158.3)$ & $49.1(20.2-123.2)$ & $p=0.08$ \\
\hline Urine mg OH proline/g creatinine/day & $18.1(8.0-33.7)$ & $14.5(6.0-89.0)$ & $p=0.322$ \\
\hline
\end{tabular}

Median (min-max.) 
Table 2. Levels of serum Ca, P, urea, creatinine, total ALP, glucose of the hyperthyroidism and control groups

\begin{tabular}{|c|c|c|c|}
\hline & $\begin{array}{l}\text { Hyperthyroidim group } \\
n=24\end{array}$ & $\begin{array}{l}\text { Control group } \\
n=24\end{array}$ & $p$ value \\
\hline Age & $37.5 \pm 10$ & $37.1 \pm 10$ & $p=0.909$ \\
\hline $9 / \sigma^{\lambda}$ & $15 / 9$ & $11 / 13$ & $p=0,384$ \\
\hline Serum Ca $(\mathrm{mg} / \mathrm{dL})$ & $9.9 \pm 0.4$ & $9.7 \pm 0.4$ & $p=0.078$ \\
\hline Serum $P(\mathrm{mg} / \mathrm{dL})$ & $3.6 \pm 0.53$ & $3.5 \pm 0.42$ & $p=0.745$ \\
\hline Serum urea $(\mathrm{mg} / \mathrm{dL})$ & $29.1 \pm 9.8$ & $26.8 \pm 6.9$ & $p=0.349$ \\
\hline Serum creatinine $(\mathrm{mg} / \mathrm{dL})$ & $0.72 \pm 0.17$ & $0.82 \pm 0.17$ & $p=0.057$ \\
\hline Serum total ALP (IU/L) & $88.7 \pm 37.6$ & $66.4 \pm 19.0$ & \\
\hline Serum glucose (mg/dL) & $96.1 \pm 7.8$ & $100 \pm 14.5$ & $p=0.247$ \\
\hline
\end{tabular}

Mean \pm S.D.

Statistically significant ${ }^{*} p<0.05$

\section{RESULTS}

Sclerostin levels did not differ significantly in the hyperthyroidism group than in the control group ( $p=$ 0.452 ) (Table 1). Table 1 summarizes the median, minimum-maximum of variables that were not statistically normally distributed and body mass index (BMI) of the hyperthyroidism and healthy groups. The TSH levels in hyperthroidism patients were lower than the ones in the healthy group $(p<0.001)$. On the other hand, serum $\mathrm{FT}_{3}(p<0.001), \mathrm{FT}_{4}(p<0.001)$, ALT $(p=0.033)$, osteocalcin $(p<0.001)$, and urine $\mathrm{mg} \mathrm{P} / \mathrm{g}$ creatinine/day excretion $(p=0.009)$ were higher in the hyperthyroidism group than in the healthy group. Table 2 summarizes the mean \pm S.D. scores of the variables which show normal distribution in both hyperthyroidism and healthy groups. Serum total ALP levels of the hyperthyroidism group were higher than those of healthy group $(p=0.014)$ (Table 2). According to ISCD-official-positions-adult; 2013, BMD z scores were measured both at lumbar spine and femoral neck in 11 patients. For 10 patients, the results were normal and for 1 patient the values were below the expected range for age $(<-2)$.

There was a significant positive correlation between sclerostin and BALP $(r=0.805, p<0.001)$ but there was no significant correlation between sclerostin and osteocalcin, $\mathrm{TSH}, \mathrm{FT}_{3}, \mathrm{FT}_{4}$, urine $\mathrm{DPD}$, urine $\mathrm{OH}$ proline. Similarly, there was a significant positive correlation between urine $\mathrm{nMol} \mathrm{DPD} / \mathrm{g}$ creatinine/day and urine $\mathrm{mg} \mathrm{OH}$ prolin/g creatinine/day $(r=0.911, p<0.001)$ and there was a significant positive correlation between osteocalcin and $\mathrm{FT}_{3}, \mathrm{FT}_{4}$ respectively $(r=0.580, p<0.001)$, $(r=0.603, p<0.001)$ in opposition to negative correlation between osteocalcin and TSH $(r=-0.474, p<0.05)$
(Table 3). Furthermore, there was no significant correlation between sclerostin and lumbar spine $\mathrm{z}$ scores $(p=0.346 ; r=-0.314)$, femoral neck $\mathrm{z}$ scores $(p=0.811$; $r=-0.082)$.

Sclerostin levels of men and women in the hyperthyroidism group [5.91 (2.59-23.12)], [6.57 (2.63-34.74)] did not differ significantly compared to those of men and women in the normal group [5.15 (2.00-32.00)], [7.32 (3.07-32.00)] $(p=0.973, p=0.237)$.

\section{DISCUSSION}

Thyroid hormones are important regulators of the skeleton that stimulate both the formation and resorbtion of bones and cause thinning in the mineralized bones (Mosekilde et al., 1977; Ben-Shlomo et al., 2001). To this end, it has been reported that the BMD decreases in patients with hyperthyroidism, and the risk of bone fractures increases (Vestergaard et al., 2000; Basset et al., 2007). It has been stated in the literature that the thyroid hormones (O'shea et al., 2012; Tsourdi et al., 2015; Wang et al., 2007) and sclerostin (Van Bezooijen et al., 2004, 2007; Lin et al., 2009; Winkler et al., 2003; Xiaofeng et al., 2005; Poole et al., 2005) were influential on bone tissue by Wnt/ $\beta$-catenin signal pathway. There were several clinical (Skowronska-Jozwiak et al., 2012, 2015) and experimental (Tsourdi et al., 2015) studies that examine the sclerostin in hyperthyroidism.

Our study involves the hyperthyroidism patient group (including multinodular goiter and Graves' disease) whose treatments have not started yet. No differences were detected between the serum sclerostin levels of the group with hyperthyroidism and the control group

Table 3. The correlation analysis between the sclerostin, thyroid hormones, bone metabolism markers $(n=48)$

\begin{tabular}{|c|c|c|}
\hline & Correlation coefficient ( $r$ ) & $p$ value \\
\hline Serum sclerostin-serum BALP & 0.805 & $* * *$ \\
\hline $\begin{array}{l}\text { Serum sclerostin-serum osteocalcin } \\
\text { Serum sclerostin- urine } \mathrm{nMol} \mathrm{DPD} / \mathrm{g} \text { creatinine/day } \\
\text { Serum sclerostin- urine } \mathrm{mg} \mathrm{OH} \text { proline/g creatinine/day }\end{array}$ & $\begin{array}{l}-0.143 \\
0.270 \\
0.208\end{array}$ & $\begin{array}{l}>0.05 \\
>0.05 \\
>0.05\end{array}$ \\
\hline Serum TSH-serum sclerostin & 0.124 & $>0.05$ \\
\hline Serum $\mathrm{FT}_{3}$-serum sclerostin & -0.003 & $>0.05$ \\
\hline Serum $\mathrm{FT}_{4}$-serum sclerostin & 0.047 & $>0.05$ \\
\hline Serum TSH-serum osteocalcin & -0.474 & * \\
\hline Serum $\mathrm{FT}_{3}$-serum osteocalcin & 0.580 & $* * *$ \\
\hline Serum $\mathrm{FT}_{4}$-serum osteocalcin & 0.603 & $* * *$ \\
\hline Urine $\mathrm{nMol} \mathrm{DPD} / \mathrm{g}$ creatinine/day-urine $\mathrm{mg} \mathrm{OH}$ proline/g creatinine/day & 0.911 & $* * *$ \\
\hline
\end{tabular}

Statistically significant ${ }^{*} p<0.05 ; * * * p<0.001$ 
in our study. This result differs from those reported by Skowronska-Jozwiak and coworkers (2012; 2015) and Tsourdi and coworkers (2015). Skowronska-Jozwiak and coworkers $(2012$; 2015) found high serum sclerostin levels in patients with hyperthyroidism when compared to the reference values. In their study, after the treatment, the sclerostin levels reduced significantly as opposed to the pretreatment levels. Tsourdi and coworkers (2015) reported that in 12 week-old- male mice with hyperthyroidism, sclerostin mRNA expression, the number of sclerostin-positive cells and serum sclerostin levels increased, trabecular and cortical bone density and cortical thickness were found to have decreased. Thus the result of the present study suggests that the sclerostin levels may change depending on the duration of exposure of the bone tissue to increased thyroid hormone levels. More detailed data may be obtained in sclerostin by following-up the patients with hyperthyroidism for longer durations; however, it is another important fact that the treatment of the patients who are diagnosed with hyperthyroidism may not be delayed.

The studies of Wang (2007) and O'Shea (2012) revealed that the thyroid hormones stimulate the Wnt signal pathway and increase bone formation in the growing bone tissues. Wang and coworkers (2007) revealed that the applied T3 on cell cultures of chondrocyte growth plaques increased the Wnt4 mRNA, protein expression and $\beta$-catenin. When the Wnt antagonists were applied, the $\beta$-catenin induced by T3 and growth plaque cell maturation was inhibited. O'Shea and coworkers (2012) reported that in 2-week old homozygote $\mathrm{Thrb}^{\mathrm{PV} / \mathrm{PV}}$ mutant mice with disturbed hypophysis-thyroid axes and increased thyroid hormone levels in circulation, they found increased bone mineral storage and increased canonic Wnt/ $\mathrm{W}$-catenin activation in the osteoblasts of rats during their growth. On the other hand, Tsourdi and coworkers (2015), in their study, examined the bones of 12 -week- old male mice in histo-morphometric terms, and determined that there was decreasing trabecular bone density in hyperthyroidism, and increased bone density in hypothyroidism. The interesting point here was, the thyroid hormones induced bone loss in bone tissues that have already completed their development and mineralization.

Poole and coworkers (2005) reported that newly-formed osteocytes lack sclerostin. However, after the primary mineralization is completed, widespread sclerostin staining occurs in adult osteocytes and in the dendrites of osteocyte channels. Taking the existing data in the literature in to account (Poole et al., 2005; Van Bezooijen et al., 2004; Van Bezooijen et al., 2007; Lin et al., 2009; Winkler et al., 2003) we consider that sclerostin may be effective on bone tissue that has completed its mineralization in the form of bone loss.

No correlation was determined between sclerostin and thyroid hormones in our study $(n=48)$. With regard to the data in the literature, we consider that the influence of thyroid hormones and sclerostin on Wnt signal pathway, taking a great deal of cofactors and antagonists in consideration, are independent from each other.

BALP is an enzyme that ensures the phosphate hydrolyze from phosphate esters during the mineralization process of the bone, and the transportation of the phosphate to the $\mathrm{OH}$ apatite crystals (Zaitseva et al., 2015). No difference was found at BALP activity in our study between the hyperthyroidism patients and the control group. A positive correlation was determined between BALB and sclerostin. Our study is in agreement with the study of Schouten and coworkers (2012) who showed that BALP existed within reference values in hyperthyroidism patients in the pre-treatment period. It was reported in the study of Van Bezooijen and coworkers (2007) that sclerostin inhibits the BALP activity stimulated with BMP and sclerostin inhibits BMP-stimulated bone formation by antagonizing the Wnt signal pathway.

We found the ALT levels and the serum total ALP activity as being significantly higher in the hyperthyroidism group than in the control group. Considering these results, we may assume that the increase in total ALP activity stems from tissues other than bone tissue.

Osteocalcin is a Gla-protein of the bone matrix, synthesized from mature osteoblasts and hypertrophic chondrocytes (Zaitseva et al., 2015). Unfortunately, osteocalcin is not only localized in cells at mineralized surfaces since it was reported that both osteocalcin mRNA and protein are synthetized at bone marrow megakaryocytes, peripheral blood platelets (Thiede et al., 1994) and at bone marrow adipocytes (Benayahu et al., 1997). The blood levels of intact osteocalcin show the bone formation theoretically. The release of immunoreactive fragments of osteocalcin to the blood is related with bone resorbtion process (Zaitseva et al., 2015). Lee and coworkers (2000) reported that the majority of the osteocalcin is stored in extracellular bone matrix, and the osteocalcin in serum is the non-absorbed part of total osteocalcin with hydroxyapatite. The results of our study are consistent with the results reported by Skowronska-Jozwiak and coworkers (2015); Nagazaka and coworkers (1997); Pantazi \& Papapetrou (2000); Barsal and coworkers (2004), who found the osteocalcin as being high in patients with hyperthyroidism. In addition, a positive correlation was determined between osteocalcin and $\mathrm{FT}_{3}, \mathrm{FT}_{4}$, and a negative correlation between the osteocalcin and TSH in our study. Schouten and coworkers (2012) revealed that the osteocalcin was within the reference limits before the treatment in hyperthyroidism. However, differing from our study Schouten measured the N-MID fragment, but we measured the intact form of osteocalcin.

Osteocalcin and BALB are both bone formation markers. In our study, in the hyperthyroidism group, osteocalcin was found to have increased compared to normals, whereas BALB levels did not differ from normals. A correlation between osteocalcin and thyroid hormones was found. The study of K. Ohishi and coworkers (1994) may help to identify these findings. In a cell culture study, they investigated the differentiation of rat calvaria osteoprogenitor cells to osteoblasts. T3 treatment on those cells resulted in the inhibition of the differentiation: T3 treatment also caused an increased functional activity of the mature osteoblasts. There was a decreased ALP activity at day 12. T3 treatment increased synthesis of ostecalcin in a dose dependent manner (Ohishi K et al., 1994).

In our study, urine DPD (Vesper et al., 2003) and $\mathrm{OH}$ proline/creatinine/day levels (Calvo et al., 1996), which are the biological markers of bone destruction, did not show significant difference in the group with hyperthyroidism when compared with the control group. This result differs from previous studies (Nagazaka et al., 1997; Akalın et al., 2002; Sabuncu et al., 2001), which reported that the urine DPD/creatinine levels were high in hyperthyroidism. However, in the present study, a positive correlation was detected between the urine DPD and urine $\mathrm{OH}$ proline levels, which is consistent with the study conducted by Ohishi and coworkers (1994). The urine parameters were 
evaluated in 24-hour urine, which is different from the previous studies.

In our study, it emerged that the urine phosphorous excretion increased in the group with hyperthyroidism. Likewise, Mosekilde and coworkers (1977) reported that the $\mathrm{Ca}$ and $\mathrm{P}$ levels were high in 24-hour urine samples in hyperthyroidism patients.

In our study which included hyperthyroidism patient group whose treatments had not started yet, no differences were determined in sclerostin levels when compared with the control group. This result makes us think that sclerostin levels might change depending on the exposure duration of the bone tissue to high levels of thyroid hormones. A long-term study, which is to examine the skeleton mineralization destruction and construction, including pre-treatment and post-treatment periods of the hyperthyroidism patients, may provide us insight on sclerostin. We also consider that the assessment of the synthesis of the sclerostin in bone tissues and the serum levels may show differences.

\section{Conflict of interest}

The authors declare no conflict of interest

\section{Acknowledgements}

We are grateful to Ümran Üstünbaş for her kindly help in the English editing of the manuscript.

\section{REFERENCES}

Akalın A, Colak O, Alatas O, Efe B (2002) Bone remodelling markers and serum cytokines in patients with hyperthyroidism. Clin Endocrinol (Oxf) 57: 125-129. doi: 10.1046/j.1365-2265.2002.01578.x

Barsal G, Taneli F, Atay A, Hekimsoy Z, Erciyas F (2004) Serum osteocalcin levels in hyperthyroidism before and after antithyroid therapy. Tohoku J Exp Med 203: 183-188. doi http://doi.org/10.1620/ tjem.203.183

Bassett JH, O'Shea PJ, Sriskantharajah S, Rabier B, Boyde A, Howell PGT, Weiss RE, Roux J-P, Malaval L, Clement-Lacroix P, Samarut J, Chassande O, Williams GR (2007) Thyroid hormone excess rather than thyrotropin deficiency induces osteoporosis in hyperthyroidism. Mol Endocrinol 21: 1095-1107 doi: https://doi.org/10.1210/ me.2007-0033

Benayahu D, Shamay A, Wientroub S (1997) Osteocalcin (BGP), gene expression, and protein production by marrow stromal adipocytes. Biochem Biophys Res Commun 231: 442-446. https://doi.org/ 10.1006/ bbrc.1997.6116

Ben-Shlomo A, Hagag P, Evans S, Weiss M (2001) Early postmenopausal bone loss in hyperthyroidism. Maturitas the European Menapouse Journal 39: 19-27. https://doi.org/10.1016/S0378-5122(00)00179-1

Bergman I, Loxley R (1963) Two improved and simplified methods for the spectrophotometric determination of hydroxyproline. Anal Chem 35: 1961-1965. doi: 10.1021/ac60205a053

Calvo MS, Eyre DR, Gundberg CM (1996) Biological markers of bone turnover. Endocr Rev 17: 333-368. https://doi.org/10.1210/edrv-174-333

Cardoso LF, Maciel LMZ, de Paula FJA (2014) The multiple effects of thyroid disorders on bone and mineral metabolism. Arq Bras Endocrinol Metab 58: 452-463. http://dx.doi.org/10.1590/00042730000003311

International Society for Clinical Densitometry (ISCD) Official Positions - Adult. Available from: http://www.iscd.org/ officialpositions/2013-iscd-official-positions-adult; 2013

Krishnan V, Bryant HU, Macdougald OA (2006) Regulation of bone mass by Wnt signaling. J Clin Invest 116: 1202-1209. doi: 10.1172/ JCI28551

Lee AJ, Hodges S, Eastell R (2000) Measurment of osteocalcin. Ann Clin Biochem 37: 432-446. https://doi.org/10.1177/000456320003700402

Lin C, Jiang X, Dai Z, Guo X, Weng T, Wang J, Li Y, Feng G, Gao $\mathrm{X}$, He L (2009) Sclerostin mediates bone response to mechanical unloading through antagonizing Wnt/ $\beta$-catenin signaling. $J$ Bone Miner Res 24: 1651-1661. doi: 10.1359/jbmr.090411

Mosekilde L, Melsen F, Bagger JP, Myhre-Jensen O, Schwartz Sorensen N (1977) Bone changes in hyperthyroidism: interrelationships between bone morphometry, thyroid function and calciumphosphorus metabolism. Acta Endocrinol 85: 515-525. doi: 10.1530/ acta. 0.0850515
Nagasaka S, Sugimoto H, Nakamura T, Kusaka I, Fujisawa G, Sakuma N, Tsuboi Y, Fukuda S, Honda K, Okada K, İshikawa S, Saito T (1997) Antithyroid therapy improves bony manifestations and bone metabolic markers in patients with Graves' thyrotoxicosis. Clin Endocrinol 47: 215-221. doi: 10.1046/j.1365-2265.1997.2401045.x

Ogilvy-Stuart AL (2002) Neonatal thyroid disorders. Arch Dis Child Fetal Neonatal Ed 87: 165-171. doi: 10.1136/fn.87.3.F165

Ohishi K, Ishida $H$, Nagata $T$, Yamauchi N, Tsurumi C, Nishikawa S, Wakano Y (1994) Thyroid hormone suppresses the differentiation of osteoprogenitor cells to osteoblasts, but enhances functional activities of mature osteoblasts in cultured rat calvaria cells. I Cell Physiol 161: 544-552

Ohıshı T, Kushida K, Takahashı M, Kawana K, Yag1 K, Kawakamı $\mathrm{K}$, Horluch $\mathrm{K}$, Inoue $\mathrm{T}$ (1994) Urinary bone resorption markers in patients with metabolic bone disorders. Bone 15: 15-20. https://doi. org/10.1016/8756-3282(94)90885-0

O'Shea P J, Kim DW, Logan JG, Davis S, Walker RL, Meltzer PS, Cheng S-Y, Williams GR (2012) Advanced bone formation in mice with a dominant-negative mutation in the thyroid hormone receptor $\beta$ gene due to activation of $\mathrm{Wnt} / \beta$-catenin protein signaling. $J$ Biol Chem 287: 17812-17822. doi: 10.1074/jbc. M111.311464

Pantazi H, Papapetrou PD (2000) Changes in parameters of bone and mineral metabolism during therapy for hyperthyroidism. J Clin Endocrinol Metab 85: 1099-1106. https://doi.org/10.1210/jcem.85.3.6457

Poole KE, van Bezooijen RL, Loveridge N, Hamersma H, Papapoulos SE, Löwik CW, ReeveJ (2005) Sclerostin is a delayed secreted product of osteocytes that inhibits bone formation. FASEB J 19: 1842-1844. doi: 10.1096/fj.05-4221 fje

Sabuncu T, Aksoy N, Arrkan E, Ugur B, Tasan E, Hatemi H (2001) Early changes in parameters of bone and mineral metabolism during therapy for hyper- and hypothyroidism. Endocr Res 27: 203-213. http://dx.doi.org/10.1081/ERC-100107181

Schouten BJ1, Prickett TC, Hunt PJ, Richards AM, Geffner ME, Olney RC, Espiner EA (2012) C-type natriuretic peptide forms in adult hyperthyroidism: correlation with thyroid hormones and markers of bone turnover. Clin Endocrinol 76: 790-796. doi: 10.1111/j.13652265.2011.04295.x

Skowrońska-Jóźwiak E, Krawczyk-Rusiecka K, Lewandowskji KC, Adamczewski Z, Lewinski A (2012) Successful treatment of thyrotoxicosis is accompanied by a decrease in serum sclerostin levels. BMC Thyroid Res 5: 14. doi: 10.1186/1756-6614-5-14

Skowrońska-Jozwiak E, Lewandowski KC, Adamczewski Z, Krawczyk-Rusiecka K, Lewiński A (2015) Mechanisms of normalisation of bone metabolism during recovery from hyperthyroidism: potential role for sclerostin and parathyroid hormone. Int I Endocrinol 2015: 948384. http://dx.doi.org/10.1155/2015/948384

Thiede MA, Smock SL, Petersen DN, Grasser WA, Thompson DD, Nishimoto SK (1994) Presence of messenger ribonucleic acid encoding osteocalcin, a marker of bone turnover, in bone marrow megakaryocytes and peripheral blood platelets. Endocrinology 135: 929-937. doi:https://doi.org/10.1210/endo.135.3.8070388

Tsourdi E, Rijntjes E, Köhrle J, Hofbauer LC, Rauner M (2015) Hyperthyroidism and hypothyroidism in male mice and their effects on bone mass, bone turnover, and the Wnt inhibitors sclerostin and Dickkopf-1. Endocrinology 156: 3517-3527. doi:https://doi. org/10.1210/en.2015-1073

Van Bezooijen RL, Roelen BA, Visser A, van der Wee-Pals L, de Wilt E, Karperien M, Hamersma H, Papapoulos SE, ten Dijke P, Löwik CWGM (2004) Sclerostin is an osteocyte-expressed negative regulator of bone formation, but not a classical BMP antagonist. J Exp Med 199: 805-814. doi: 10.1084/jem.20031454

Van Bezooijen RL, Svensson JP, Eefting D, Visser A, van der Horst G, Karperien M, Quax PHA, Vrieling H, Papapoulos SE, ten Dijke P, Löwik CWGM (2007) Wnt but not BMP signaling is involved in the inhibitory action of sclerostin on BMP-stimulated bone formation. I Bone Miner Res 22: 19-28. doi: 10.1359/jbmr.061002

Vesper HW, Audain C, Woolfitt A, Ospina M, Barr J, Robins SP, Myers GL (2003) Highperformance liquid chromatography method to analyze free and total urinary pyridinoline and deoxypyridinoline. Anal Biochem 318: 204-211. https://doi.org/10.1016/S00032697(03)00241-0

Vestergaard P, Rejnmark L, Weeke J, Mosekilde L (2000) Fracture risk in patients treated for hyperthyroidism. Thyroid 10: 341-348. https://doi.org/10.1089/thy.2000.10.341

Wang L, Shao YY, Ballock RT (2007) Thyroid hormone interacts with the Wnt/beta-catenin signaling pathway in the terminal differentiation of growth plate chondrocytes. J Bone Miner Res 22: 1988-1995. doi: $10.1359 /$ jbmr.070806

Winkler DG, Sutherland MK, Geoghegan JC, Yu C, Hayes T, Skonier JE, Shpektor D, Jonas M, Kovacevich BR, Staehling-Hampton K, Appleby M, Brunkow ME, Latham JA (2003) Osteocyte control of bone formation via sclerostin, a novel BMP antagonist. EMBO J 22: 6267-6276. doi 10.1093/emboj/cdg599

Xiaodong L, Ominsky MS, Niu Q-T, Sun N, Daugherty B, D'Agostin D, Kurahara C, Gao Y, Cao J, Gong J, Asuncion F, Barrero M, Warmington K, Dwyer D, Stolina M, Morony S, Sarosi I, Koste- 
nuik PJ, Lacey DL, Simonet WS, Ke HZ, Paszty C (2008) Targeted deletion of the sclerostin gene in mice results in increased bone formation vand bone strength. J Bone and Miner Res 23: 860-869. doi: $10.1359 /$ jbmr.080216

Xiaofeng Li, Zhang Y, Kang H, Liu W, Liu P, Zhang J, Harris SE, Wu D (2005) Sclerostin binds to LRP5/6 and antagonizes canoni- cal Wnt signaling. J Biol Chem 280: 19883-19887. doi: 10.1074/jbc. M413274200

Zaitseva OV, Shandrenko SG, Veliky MM (2015) Biochemical markers of bone collagen type I metabolism. Ukr Biochem J 87: 21-32. UDC 577.11:611.018.43 